\title{
Dynamic Assessment of IELTS Writing Task One through Mobile Learning in the Context of Iranian EFL Learners
}

\author{
Leila Moeinpour (Corresponding author) \\ Department of English Language, University of Zanjan \\ PO Box 4537138791, Zanjan, Iran \\ E-mail: Leila.moeinpour@ alumni.znu.ac.ir \\ Mahdi Nasiri \\ Department of English Language, University of Zanjan \\ PO Box 4537138791, Zanjan, Iran \\ E-mail: mahdinasiri@znu.ac.ir \\ Aiyoub Jodairi Pineh \\ Department of English Language, University of Zanjan \\ PO Box 4537138791, Zanjan, Iran \\ E-mail: j.pineh@znu.ac.ir
}

Nikoo Davarpanah

Department of English Language, Islamic Azad University of Zanjan

PO Box 4515658145, Zanjan, Iran

E-mail: Davarpanahnikoo24@gmail.com

Received: January 8, 2019 Accepted: January 23, 2019 Published: January 26, 2019

doi:10.5296/ijele.v7i1.14273 URL: https://doi.org/10.5296/ijele.v7i1.14273 


\begin{abstract}
Dynamic as sessment is an approach primarily based on sociocultural theory of mind with the objective of combining instruction and assessment. In this approach learners' development is simultaneously assessed regarding their Zone of Proximal Development. The present study was intended to investigate the effect of Mobile-Assisted Dynamic Assessment (MADA) on IELTS writing task one and also the EFL learners' perception to such approaches toward language learning. In order to achieve the aim of this quasi-experimental study, a social networking application, namely Telegram was applied on mobile phones. Based on the scores on the Oxford Quick Placement Test, twenty-three Iranian advanced-level EFL learners out of a population of 40 students participated in this study. An intact group went through a pre-testtreatment-post-test process. In the end, the participants were interviewed for their perceptions on mobile assisted dynamic assessment which was used to assess their writing skill. The results of the data analysis revealed that the participants experienced improvement in their writing after the treatment and obtained a significant increase in their scores of the post-test, and they benefited from the process of dynamic assessment through online mobile-learning environment. They further had a positive perception towards MADA.
\end{abstract}

Keywords: Mobile assisted language learning (MADA), Dynamic assessment, IELTS writing, EFL learners, ZPD, Mobile application, Telegram

\title{
1. Introduction
}

Assessment is of high importance in the context of teaching and learning in. Dynamic assessment (DA) as a specific kind of assessment provides corrective feedback which emphasizes the process of learning (Haywood \& Lidz, 2006). English language teachers and instructors using dynamic assessment in conventional classrooms teach the same content to all students. In this kind of assessment, individual needs and difficulties are not taken into consideration. In this type of learning system, it may be difficult for students to maximize their learning outcome. Dynamic assessment in conventional classrooms may hinder learners' performance as their English proficiency levels are heterogeneous, hence providing the same feedback may seem inadequate or demotivational to some students who do not need that feedback. Therefore, it is necessary to design a personalized environment to accommodate each student's needs for learning a foreign language.

There have been innovative technologies which can affec language learning and education. The recent developments in mobile-based learning provided home works to increase users' motivation and learning outcomes. The rapid advances in wireless communication technologies and mobile devices have brought significant changes to the way people receive, disseminate, and apply information. Such technological advances have also created a novel learning mode such as mobile learning (m-learning) (Chinnery, 2006; Soloway et al., 2001). Learners may usually encounter significant challenges in developing their writing performance on the IELTS test. This chapter begins with stating the problem and presents the significance and purpose of the study. Then, it introduces the research questions and 
hypotheses. Following this, the definition of key-terms is provided. The last part of the chapter deals with the limitations and delimitations of the study.

\section{Literature Review}

\subsection{Dynamic Assessment}

\subsubsection{Theoretical Background of DA}

The theoretical background of dynamic assessment traces back on Vygotsky's point of Zone of Proximal Development (ZPD) and the concept of mediation, which influences the mental development of a person. Mediation is a process which refers to the transfer of data from instructors to learners within the area called ZPD, which differentiates between learners' actions and capabilities without help and their capabilities and performance with the help of instructors. Vygotsky asserts that, "The zone of proximal development furnishes psychologists and educators with a tool through which internal course of development can be understood. By using this method we can take account of not only the cycles and maturation processes that have already been completed but also those processes that are currently in a state of formation (Vygotsky, 1978, p. 33).

Based on ZPD, where learning can happen and proceed, the main objective is to proceed information from what the learners' can perceive with help into the mastery zone. According to Aljaafreh and Lantolf (1994), there is a difference between learner's present and future development level of performance. Bearing the concept of ZPD in mind, teachers and instructors aid their learners to think logically and conduct scientific concepts by interacting in the context of assisted performance. As Vygotsky states "The zone of proximal development permits us to delineate the child's immediate future and his dynamic developmental state, allowing not only for what already has been achieved developmentally, but also for what is in the course of maturing (Vygotsky, 1978, p. 33).

According to Lantolf and Poehner (2008), the significant characteristic of dynamic assessment is that it merges instruction and assessment and unites teachers and students, and it emphasizes on students' future development through their zone of proximal development. In this way, the real potential of the children is assessed, and assessment becomes a continuous process.

Feuerstein used the concept of ZPD-based dynamic assessment that was the contribution of Vygotsky. He asserted that DA assesses the real potential of the individual. According to Feuerstein (2002), DA is a kind of psychological assessment in which intervention is embedded within the process of assessment.

Sternberg and Grigorenko (2002) mentioned that there are three phases in the procedure of dynamic assessment (pre-test, treatment, and post-test), which is called sandwich format. In the first phase, the examiner provides the testee with a test in order to observe his abilities in a task; in the second phase, the testee is assisted in tasks which are similar to the one in the first phase. The instructor provides hints, suggestions, ramifications, and feedback in this 
phase; in the third phase, which is called post-test, the examiner tests the testee once again.

\subsubsection{Empirical Studies on Dynamic Assessment}

Numerous studies have investigated and explored the concept of dynamic assessment in different fields. In the field of language teaching and learning, many researchers have studied the effect of dynamic assessment on different skills. Mirzaei, Shakibaei, and Jafarpour (2017) performed a study of a group-dynamic assessment on EFL learners' vocabulary knowledge. They concluded that learners benefited from applying interactionist cumulative group-DA in increasing their depth of vocabulary knowledge. Ramazanpour (2016) considered the difference between male and female EFL learners in conducting a research on the effect of DA on the grammatical accuracy of writing. It was found that regarding the effect of DA on grammatical accuracy, there is no difference between male and female learners. Khoshsima, Saed, and Mortazavi (2016) intended to provide feedback through implementing interactionist dynamic assessment to teach explanation genre writing among BA students of English translation in the Iranian context. The findings of their study showed that students could perform better when dynamic assessment implemented to the instruction due to the feedback provided through negotiation.

Aghaebrahimian, Rahimirad, Ahmadi, and Alamdari (2014) conducted a study to explore the effectiveness of dynamic assessment on the writing ability among Iranian advanced learners. The results of their study revealed a significant change in the writing ability of participants due to the implication of dynamic assessment. In a study by Parsi and Sanavi (2015), the impact of teaching two techniques including Form-Focused Instruction and Conference Writing was investigated among Iranian intermediate EFL learners. The results of the study indicated that Conference Writing had a positive effect on learner's writing ability by helping teachers to implement dynamic assessment in the classroom and to identify the learners' errors through mediation.

In a study by Yakisik and Cakir (2017), the effects of DA on English learners' speaking skills were investigated. They followed the pre-test - treatment-post-test procedure in the study. The results of analyzing statistical data revealed significant effects of dynamic assessment on the experimental group and as well as the positive perception of learners' towards the assessment procedure. A study by Davin (2016) revealed that the implementation of DA in language classrooms of an elementary school provided opportunities for the teacher to mediate and help learners to reformulate their produced materials. He reported that using DA in the whole classroom requires skilled teachers and instructors and DA should be a part of teacher education program. The role of DA in improving the oral proficiency skills of English learners was investigated by Weisgerber (2015). The results showed that DA could facilitate the development of grammatical and lexical abilities and cause greater use of cognitive and metacognitive strategies among learners.

\subsection{Mobile Assisted Language Learning}

Rapidly increasing use of smartphones and mobile applications have provided new opportunities for language learning and teaching inside and outside of the classroom. Mobile 
phones make the process of language learning and teaching more manageable from any place regardless of time, without any restrictions. Mobile technologies have resulted in significant changes in language learning and teaching. English language teaching and its practices have also been affected by this paradigm flow of change, as well (Stockwell, 2010). The immense power of Mobile assisted language learning (MALL) technologies can assist more innovative educational methods (Sung, 2016).

Due to the distinctive features of mobile devices such as availability, portability, easy to handle, etc. there has been a wide range of use of these devices in educational settings that offers a more flexible environment for learners as well as educators. Educators can provide contents and materials related to language learning through mobile devices by using some features such as access to the internet, short message service ( SMS), multimedia messa ging service (MMS) instant messaging applications, audio/ video players on these devices, etc.

Mobile learning provides a cooperative environment for learning process in which learners can interact with each other even outside the classroom. It motivates learners to use their free time to learn a foreign language (Isik \& Cukurbasi, 2012). This kind of learning makes the learners relaxed as they are not required to sit in the classroom or at the table at home to use a computer to learn the language by getting the materials. They are able to use their mobile devices outside or at work, or while they are commuting.

The internet and social media are technological advances which have affected people's lives in different ways. Education is one of these aspects, which has been influenced by the emerging advances in social media and networking. Language learning is a social and interactive phenomenon. Social networking applications on mobile devices can provide a distant learning environment for learners through which they are able to communicate and engage in internet chat rooms or instant messaging systems. In mobile-learning, learners need to interact with each other by using internet on their mobile devices. They can participate and communicate in real-time situations in online conversations through social media application on their mobile devices. "Mobile-Assisted Language Learning (MALL) deals with the use of mobile technology in language learning. In contrast to classroom learning, in MALL there is no need for the learners to sit in a classroom or at a computer to get learning materials. In fact, MALL can be considered an ideal solution to language learning barriers in terms of time and place" (Mosavi Miangah \& Nezarat, 2012).

According to Theo Dunnewijk and Staffan Hultén (2006), mobile devices were invented in 1973 by John F Mitchell and Martin Cooper. The second generation of this technology (2G) was invented in Finland. In 2001, the Japanese started to use the third generation (3G) of this technology, and numerous companies launched new versions of these devices. In the new epoch of technology, there has been an urge for the use of mobile devices in an educational context which grants the opportunity to the learners to interact in an authentic context and improve their mastery (Scott W. Campbell, 2002). Using mobile devices in an effective way can provide opportunities for instructors and teachers to conduct, create, and convey their content materials, monitor learners' participation, and assess their performance via mobile devices. Kukulska-Hulme and Shield (2008) looked into the influence of efficacy of mobile 
devices in supporting the teaching and learning process.

In addition to this technology, by the advent of the internet, there has been a wide range of distance learning which allows learners to access educational contexts from different parts of the world. In distance learning context, learners do not get the urge to study a second or foreign language in a classroom.

\subsubsection{Empirical Background on MALL}

There have been numerous studies on the use of mobile devices as educational tools in teaching and learning language skills. Chen, Carger, and Smith (2017) explored the effects of scaffolding learners' narrative writing skills via using tablets. They reported a significant increase in learners' motivation and their quality of narrative writing due to the use of mobile technology. Kham Sila, Jocelyn, and Sudweeks (2017) developed a framework for helping non-native English migrant women in acquiring English vocabulary with the support of mobile assisted language learning (MALL). The findings of their study showed that migrant women had significantly enriched and positive vocabulary learning Experience in MALL environment.

Foomani and Hedayati (2016) conducted a study on MALL in a seamless learning approach. They reported the effectiveness of mobile devices on learning English idioms and concluded that the participants favor the learner autonomy achieved by learner-generated context. In another study by Tarighat and Khodabakhsh (2016), the feasibility of assessment through mobile devices was investigated by using electronic portfolios and a social networking application (WhatsApp). Due to the lack of authentic communication, it was concluded that the mobile-assisted language assessment should be used alongside the other forms of assessment.

\subsection{Academic Writing}

Many approaches have probably emphasized the role of writing development. Understanding what is done while writing and how the writing task is approached, may guarantees learners' success in academic writing. One can start writing after figuring everything out. Justifying the opinion in the mind is much more complicated, especially when learners need to put their opinion into words which bear the reason that they have in their head (Ellis, 2009). The writing module of IELTS, is one of the sections of the exam which tests the students' ability in the English language. This section itself has 2 parts: academic writing task one and academic writing task two.

The first step in academic writing is to find a reason to write, which means finding a question about which to get curious. Since critical thinking is designed to help thinkers to be aware of the way that they think things through, a critical question would be designed to guide the student away from questions that would produce cognitive bias. That does not mean it is easy (Vallis, L., G., 2010). In this way, a critical question may not be a set of rules but a learning tool- a guide to help a writer to avoid bias, but also to understand what constitutes a question that will yield further thinking. 


\section{Macrothink}

The questioning technique is used in the writing section of IELTS test. This technique is an effective way of motivating students to write. By implementing this technique in teaching writing skills, students' critical thinking has been developed, which helps students to think critically and actively participate in writing actively (Brown \& Hill, 1998).

\section{Methodology}

\subsection{Research Questions and Hypothesis}

The aim of this study was to answer the following questions:

1. Does mobile-assisted dynamic assessment improve IELTS writing task one quality by Iranian advanced EFL learners?

2. What is the Iranian EFL learners' perception of the mobile-assisted dynamic assessment for the IELTS writing task one?

The following null hypothesis was formulated in order to answer the first research question:

H0: Mobile-assisted dynamic assessment is not significantly effective in developing IELTS writing task one by EFL learners.

\subsection{Research Design}

This research study reports on a quasi-experimental study regarding the effectiveness of dynamic assessment on writing task s of the participants in the intact group through the online mobile environment. In order to gather the appropriate data to obtain a more complete understanding of the research questions, a mixed methods design based on the classification provided by Creswell and Plano Clark (2011) was applied. It involved collecting quantitative data first, and then incorporating the perspectives of the individuals by qualitative data

\subsection{Participants}

The participants of the study consisted of the advanced Iranian EFL learners in Jahad Daneshgahi Institute of Zanjan, Iran. The researcher applied convenience sampling in order to select the participants. Twenty-three advanced EFL learners participated in this study. The ages of the participants were between 18 to 30 years old; they were learning English as a foreign language. As these participants all were studying the same course of English, they were all advanced learners. The focus of the study was on the effect of the dynamic assessment on IELTS writing task one through mobile learning among female learners. They had the same level of proficiency and the same native language, hence they participated OQPT and were homogeneous in terms of English language knowledge.

\subsection{Instruments and Material}

\subsubsection{Oxford Quick Placement Test}

In order to measure the proficiency level of the participants, the Oxford Quick Placement Test was applied. According to Geranpayeh (2006), OQPT as a standardized English proficienc y 
test has been tested and validated in 60 countries. As stated by Allan (2004, as cited in Rashidi and Mirsalari, 2016), this test has been rated against the proficiency levels based on the Common European Framework of Reference for Languages (CEF), the Cambridge ESOL Examinations, and other major international examinations such as TOEFL. In order to measure the reliability of the test, Cronbach's alpha was calculated. The resulting $\alpha$ coefficient of reliability ( $\alpha=0.707,0>\alpha>1$ ), indicates that the items have shared acceptable covariance and they measure the same underlying concept. This proves the reliability of the placement test used in this study.

\subsubsection{Interview}

In order to obtain qualitative insight into the perception of the participants about the program, a semi-structured interview with a set of pre-determined questions was conducted to explore themes and further response.

\subsection{Procedure}

The procedure of data collection for this study includes implementation of a placement test, pre-test, treatment, and a post-test. Independent variable mobile assisted dynamic assessment, and a dependent variable was IELTS writing task one. In order to identify the learners' level of general English language and select advanced ones, a placement test was applied. Those who scored a grade 70-79 based on a cut-off score made by Allen, 2004, were classified as advanced level learners. Then these students received treatment through mobile application telegram and a post-test was administered to the group after the treatment. Finally, the results derived from pre-test and post-test were compared.

The procedures of the research were explained clearly to the participants and they were informed that the information obtained in this study was confidential. The IELTS writing test of task one was used for the purpose of assessing the writing ability of the learners. This test was also applied for the post-test.

At the first step of the study, forty students took part in Oxford Quick Placement Test, and twenty-three EFL learners were selected as the participants of this study. The purpose of using this test was to select advanced-level students.

In the second step, one topic was given to the participants as a pre-test and they were asked to write about it. The students had 20 minutes to give their first writings to the teacher. Each writing sample was scored independently by each rater, and an inter-rater reliability was calculated.

The third step of the study was carried out by applying dynamic assessment through the telegram mobile application. The content of the course was constructed by the researcher in a more comprehensible and explicit way in order to motivate students to write without being confused or frustrated. In order to assess learners' writings dynamically, the researcher as a teacher in this study went through the treatment by using telegram application and having online connection individually with each learner out of the classroom for four weeks. 
In presenting the mediation to the experimental group, the students were informed about their problems in the texts, then these problematic areas of the writings in the pre-test of students were considered and with the purpose of helping them for writing better reports, some suggestions were given to them. Accordingly, during the 10 sessions of mediation, in order to motivate the students to write and actively participate in writing task, the questioning task was used as an effective way. Some critical questions about the diagrams were selected from the material provided from complete IELTS series and used as a learning tool to guide the learners away from questions that would produce cognitive bias and help them to understand what constitutes a question that would yield further thinking. Also, based on the needs of the students and the kind of the problem, the suggestions were presented to the students implicitly (by an example in a sentence) or explicitly (by giving explanations).

As a fourth step, after the 10th session, the subjects were given the second topic. The second writing as a post-test was given 20 minutes in order to achieve the main goal of the research, which was investigating the effect of treatment (instruction through a mediated learning experience) and subjects were supposed to write it according to the information they received during the course. As the aim of the researcher was to consider the criteria, such as task achievement, coherence and cohesion, lexical resource, and grammatical range, the effect of topic variation was not taken into account in analyzing the results.

As the fifth step, in order to obtain qualitative insight into the perception of the participants about the program, a semi-structured interview with a set of pre-determined questions was conducted through telegram for exploring themes and further responses.

The data obtained from both sections of the pre-test and post-test went through descriptive and inferential statistics. Accordingly, the results showed the frequency, mean, and standard deviation values for both of the pre-test and post-test scores, both totally and separately.

\subsection{Data Analysis}

The first research question of the study aims at investigating whether there is any significant effect of mobile-assisted dynamic assessment on learners' IELTS writing task one score. In order to obtain a more succinct answer to this question, the scores obtained from the pre-test and post-test part of the research were analyzed.

Table 1. Paired Samples Statistics for Pre-test and Post-test scores

\begin{tabular}{|l|l|l|l|}
\hline & Mean & Std. Deviation & Std. Error Mean \\
\hline Pair 1 pre-test 1 & 5.9348 & $\begin{array}{l}1.18996 \\
1.23158\end{array}$ & 0.24812 \\
& & & 0.25680 \\
Post-test 1 & 6.3043 & & \\
\hline Pair 2 pre-test 2 & 5.9130 & 1.15456 & 0.24074 \\
\hline
\end{tabular}




\begin{tabular}{|l|l|l|l|}
\hline & & 1.21299 & 0.25293 \\
Post-test 2 & 6.3043 & & \\
\hline
\end{tabular}

Note. $N=23$.

The descriptive statistics of the pre-test and post-test scores are presented in Table 1. As it is indicated in this table, the mean score for the pre-test is 5.9348, and the mean score for the post-test is 6.3043. Based on this table, the difference between pre-test and post-test mean scores indicated that the participants experienced improvement in their writing after the treatment and we can conclude that they did better in post-test than pre-test.

Table 2. Paired Samples $t$-Test Results for Pre-test and Post-test scores

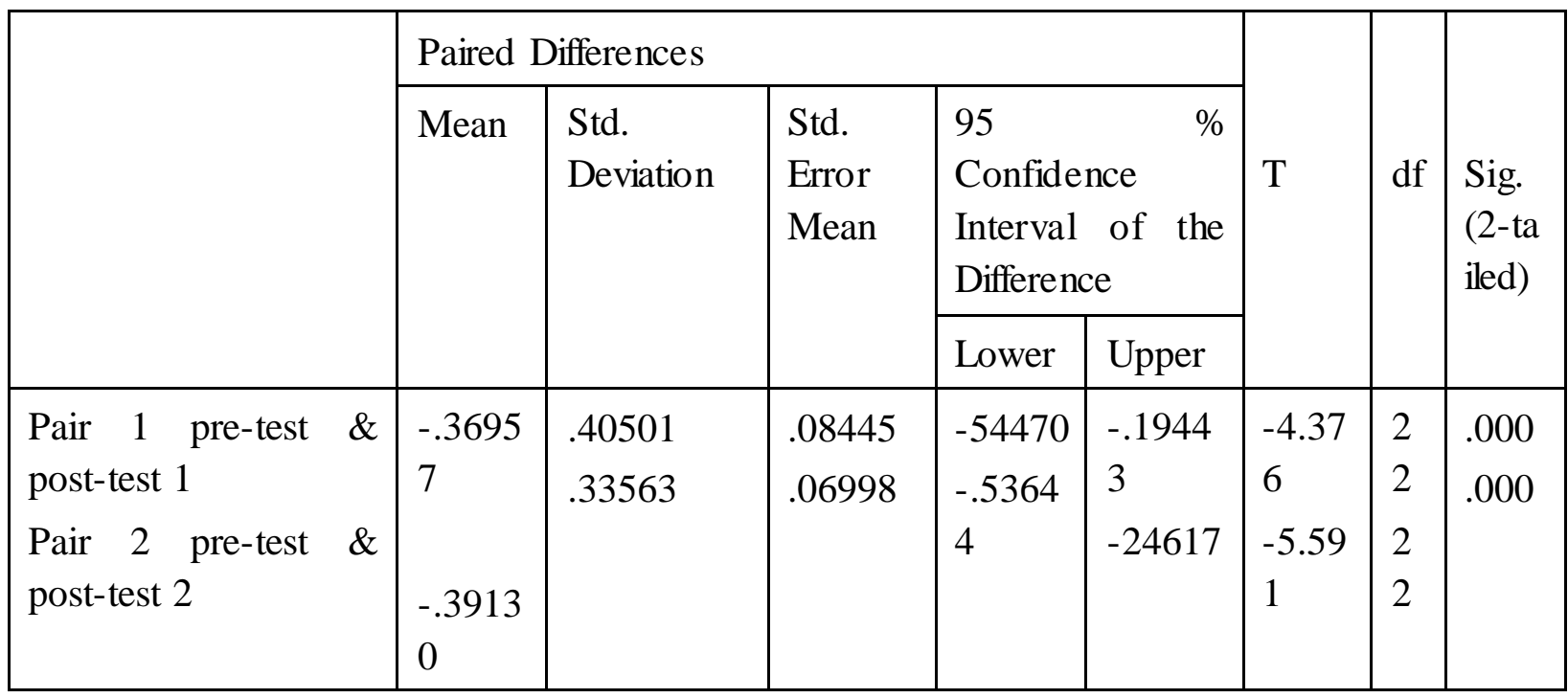

Note. $N=23 . \mathrm{p}<0.05$

According to the results of the paired sample t-test (table 2), the level of significance (2-tailed) value or $\mathrm{p}$-value is 0.000 for pair 1 (pre-test 1 -post-test 1 ) and it is also 0.000 for the second pair (pre-test 2-post-test 2). The level of significance for both pre-test and post-test is less than the probability value $(\mathrm{p}<0.05)$. Therefore, it can be concluded that there is a significant difference between pre-test and post-test scores, and it can be claimed that the participants took advantage of mediation and intervention and obtained a reasonable increase in their scores of the post-test $(0.000<0.05)$.

\subsubsection{The Analysis of the Qualitative Data}

In order to gather the qualitative data on the participants' perception of mobile assisted dynamic assessment, a semi-structured interview, including a series of questions with accompanying queries that probed for more detailed and contextual data, was conducted via 
telegram. Metaphor analysis was used as a research tool in this study. In education research, metaphor analysis has long been used as a heuristic to raise awareness about theoretical assumptions, challenge established beliefs, and promote change in classroom (Guerrero \& Villamil, 2001). Lakkof and Johnson (2003) suggested that metaphors are not merely linguistic ornaments, but an expression of the structure of thought. All participants $(\mathrm{N}=23)$ provided their answers to the series of open-ended questions by chatting with the researcher via telegram. In this study, 163 metaphors developed by the participants were identified and assigned to 10 categories. These categories were transferred to SPSS with coding. The percentage and frequency of the metaphors were calculated. Categories belonging to participants' evaluation of the program via semi-structured interviews, were calculated.

Table 3. The Frequency, percentage and Examples of the Metaphors obtained from Students' Evaluation of the MADA Program

\begin{tabular}{|l|l|l|l|}
\hline category name & Example & F & Percentage \\
\hline Effectiveness & $\begin{array}{l}\text { I think that this program was very effective for } \\
\text { me. }\end{array}$ & 15 & $9.22 \%$ \\
\hline Motivation & $\begin{array}{l}\text { Using telegram in learning writing was really } \\
\text { interesting. }\end{array}$ & 20 & $12.26 \%$ \\
\hline Self-confidence & $\begin{array}{l}\text { When I was communicating via this program, I } \\
\text { felt more confident. }\end{array}$ & $8.58 \%$ \\
\hline Face-saving & $\begin{array}{l}\text { I could communicate much better than face-to } \\
\text { face classes. }\end{array}$ & 5 & $3.06 \%$ \\
\hline Stress-free & $\begin{array}{l}\text { I did not have any stress during the dynamic } \\
\text { assessment session on telegram. }\end{array}$ & 16 & $9.81 \%$ \\
\hline Time-saving & $\begin{array}{l}\text { I didn't have to go out of home and spend } \\
\text { more time to arrive to the class. }\end{array}$ & 13 & $8 \%$ \\
\hline Useful & $\begin{array}{l}\text { The program was really beneficial to me by } \\
\text { providing feedbacks and examples. }\end{array}$ & 22 & $13.49 \%$ \\
\hline Success & $\begin{array}{l}\text { I could really achieve to higher level in writing } \\
\text { task by using this program. }\end{array}$ & 16 & $22 \%$ \\
\hline Positive & $\begin{array}{l}\text { I could use the program whenever and } \\
\text { wherever I could regardless of time and place. }\end{array}$ & 20 & $13.49 \%$ \\
\hline
\end{tabular}




\begin{tabular}{|l|l|l|l|}
\hline perception & & & \\
\hline & Total & 163 & $100 \%$ \\
\hline
\end{tabular}

Table 4.4 continued. Note. $N=23 . \mathrm{F}=$ frequency. Total number of metaphors=163

According to the data presented in table 3, the participants developed 22 metaphors related to the positive perception category. The metaphor analysis of the answers indicated the willingness of the participants in using the program. The participants developed totally 22 metaphors related to the "useful" category. They linked the MADA program mostly to its availability as sated with an example below:

I could use the program whenever and wherever I could regardless of time and place.

As indicated in table 3, the participants also related the advantages of this program in teaching and testing and showed their gratitude toward the application of MADA in teaching and testing the writing skill by providing their metaphors for "usefulness category", and the reasons regarding the criteria of effectiveness and motivation follow as this:

The program was really beneficial to me by providing feedbacks and examples.

I think that this program was very effective for me.

Using telegram in learning writing was really interesting.

According to the data in table 3, the participants related few metaphors to "face-saving" category, which indicates their willingness to face-to-face interactions. Based on the results of the metaphor analysis, almost all participants had positive perceptions towards the program. The results coming out of the frequency table provided answer for the second research question of this study. It was concluded that they evaluated the program effective and useful.

\section{Conclusion}

This study aimed to fill the gap for writing performance intervention research that focused on meetings needs of EFL learners who are in the process of acquiring English as a foreign language and who have been participated in IELTS preparation courses. The focus of the dynamic assessment aimed to equip participants with strategies to construct reports on IELTS writing task one. Results indicated a significant effect of MADA on EFL learners' writing performance. As evidenced in Parsi and Sanavi (2015) and Najmi (2015), the mobile-based dynamic assessment engaged participants as active learners who could regulate use of prompts and hints in their writings. Therefore, situated within the context of results found for Iranian EFL learners, integrating instruction and assessment in the evaluation of writing performance and MADA procedure played a role in equipping participants with the tools and strategies needed to approach the task one of writing on IELTS test. Also, the results of metaphor analysis which was conducted to explore participants' perception, indicated their positive perception of mobile assisted dynamic assessment of IELTS writing task one. 


\section{Pedagogical Implications and Recommendations}

Despite the problems of generalizability, the findings of this study have a number of implications in the field of teaching and assessment. In this study, a significant increase was observed in the scores of the learners on the ability of IELTS writing task one due to the mediation through intervention and interaction via the mobile-based online environment. According to this finding, some conclusions can be made. For instance, the instruction provided for the learners should be slightly above their level of cognitive development.

According to Stremmel and Fu (1993), the teacher plays a significant role in providing a supportive context for encouraging the learners' learning during the dynamic assessment approach. Significantly the teacher as a mediator is responsible for making a decision on providing and incorporating a scaffolding into assessment by recognizing each learner's level and abilities. This online personalized environment via mobile devices provides the teacher with an opportunity to incorporate supportive approach and especial scaffolding according to each learner's needs. Outside of the class, mobile devices are used as mediational tools while studying English. The teacher could provide more individualized and personalized feedback to each learner via online mobile assisted dynamic assessment.

The present study attempted to apply a mobile assisted dynamic assessment approach for assessing IELTS writing task one. Further future research in this area requires focusing on the suggestions that follow. This study was limited to only one type of dynamic assessment that is the online learning experience, so future studies can focus on the other types of dynamic assessment related to the classroom. Also, future research is required to focus on the type and amount of mediation required in the process of dynamic assessment.

The sample of this study included only the advanced proficiency level learners. Future research can investigate the effect of mobile assisted dynamic assessment on the learners of other levels of proficiency. Besides writing, mobile assisted dynamic assess ment can be done with other types of writings and language skills. The effect of mediation provided to the learners is different from learner to learner because the degrees of responsiveness to the mediation or instruction are not the same. Therefore, the extent to which different learners benefit from the online assistance requires further investigations.

\section{References}

Ableeva, R. (2008). The effects of dynamic assessment on L2 listening comprehension. In J.P. Lantolf and M. E. Poehner (Eds.) Sociocultural theory and the teaching of second languages. London: Equinox Press, 57-86.

Aghaebrahimian, A., Rahimirad, M., Ahmadi, A., \& Alamdari, J. K. (2014). Dynamic assessment of writing skill in advanced EFL Iranian learners. Procedia-Social and Behavioral Sciences, 98, 60-67. http//dx.doi.org/10.1016/j.sbspro.2014.03.389 
Ahmad, K. S., Armarego, J., \& Sudweeks, K. (2017). The impact of utilising mobile assisted language learning (MALL) on vocabulary acquisition among migrant women English learners. Interdisciplinary Journal of eSkills and Lifelong Learning, 13, 37-57. Retrieved from http://www.informingscience.org/Publications/3703

Aissa, H. A. N. I. F. I. (2015). The Second Language Influence on Foreign Language Learners' Errors: the Case of the French Language for Algerian Students learning English as a Foreign Language. The Online Journal of New Horizons in Education, 5(3), 124.

Ajideh, P., \& Nourdad, N. (2012). The effect of dynamic assessment on EFL reading comprehension in different proficiency levels. Language testing in Asia, 2(4), 101.

Alavi, S. M., \& Taghizadeh, M. (2014). Dynamic assessment of writing: The impact of implicit/explicit mediations on L2 learners' internalization of writing skills and strategies. Educational Assessment, 19(1), 1-16. https//doi.org/10.1080/10627197.2014.869446

Aljaafreh and Lantolf, 1994 Aljaafreh, A., \& Lantolf, J. P. (1994). Negative feedback as regulation and second language learning in the zone of proximal development. The Modern Language Journal 78, 465-483. https://doi.org/10.1111/j.1540-4781.1994.tb02064.x

Birjandi, 2012 Birjandi, P \& Ebadi, S. (2012). Microgenesis in dynamic assessment of L2 learners' sociocognitive development via web 2.0. Procedia Social and Behavioral Sciences 32, 34-39. https://doi.org/10.1016/j.sbspro.2012.01.006

Burston, J. (2013). Mobile-assisted language learning: A selected annotated bibliography of implementation studies 1994-2012. Language Learning \& Technology, 17(3), 157-224. Retrievable from http://lt.msu.edu/issues/october2013/burston.pdf

Cacchione, A. (2015). Creative use of Twitter for Dynamic Assessment in Language Learning classroom at the university. Interaction Design and Architecture(s) Journal, IxD\&A, 24, 145-161.

Chalak, A. (2017). Linguistic Features of English Textese and Digitalk of Iranian EFL $\begin{array}{llll}\text { Students. } \quad \text { Research } & \text { in }\end{array}$ https://doi.org/10.22055/RALS.2017.12870

Chen, Y., Carger, C. L., \& Smith, T. J. (2017). Mobile-assisted narrative writing practice for young English language learners from a funds of knowled ge approach. Language Learning \& Technology, 21(1), 28-41. Retrieved from http://lt.msu.edu/issues/february2017/chencargersmith.pdf

Chinnery, G. M. (2006). Emerging technologies. Going to the mall: mobile assisted language learning. Language learning \& technology, 10(1), 9-16. Retrieved from http://lt.msu.edu/vol10num1/emerging/

Davin, K. J. (2016). Classroom Dynamic Assessment: A Critical Examination of Constructs and Practices. The Modern Language Journal, 100(4), 813-829. https://doi.org/10.1111/modl.12352 


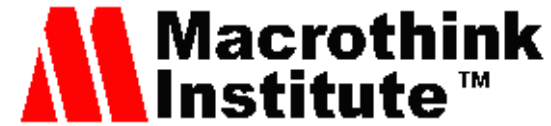

Feuerstein, R. (2002). The dynamic assessment of cognitive modifiability: The learning propensity assessment device: Theory, instruments and techniques. ICELP Press.

Foomani, E. M., \& Hedayati, M. (2016). A seamless learning design for mobile assisted language learning: An Iranian context. English Language Teaching, 9(5), 206. http://dx.doi.org/10.5539/elt.v9n5p206

Haywood, H. C., \& Lidz, C. S. (2006). Dynamic assessment in practice: Clinical and educational applications. Cambridge University Press.

Joanes, D. N., \& Gill, C. A. (1998). Comparing measures of sample skewness and kurtosis. Journal of the Royal Statistical Society: Series D (The Statistician), 47(1), 183-189. https://doi.org/10.1111/1467-9884.00122

Khoshsima, H., Saed, A., \& Mortazavi, M. (2016). The Impact of Interactionist Dynamic Assessment on Explanation Writing Ability of Intermediate EFL Learners. International Journal of Language and Linguistics, 4(5), 183-189. https://doi.org/10.11648/j.ij1l.20160405.13

Kukulska-Hulme, A., \& Shield, L. (2008). An overview of mobile assisted language learning: From content delivery to supported collaboration and interaction. ReCALL, 20(3), 271-289. https://doi.org/10.1017/S0958344008000335

Lantolf and Poehner, 2011b Lantolf, J. P. \& Poehner, M. E. (2011b). Dynamic Assessment in the Foreign Language Classroom. A Teacher's Guide. (2nd ed.) The Pennsylvania State University, Center for Advanced Language Proficiency Education and Research.

Lantolf, J. P., \& Poehner, M. E. (2004). Dynamic assessment of L2 development: Bringing the past into the future. Journal of Applied Linguistics, 1(1), 49-72.

Lantolf, J. P., \& Poehner, M. E. (2011). Dynamic assessment in the classroom: Vygotskian praxis for second language development. Language Teaching Research, 15(1), 11-33. https://doi.org/10.1177/1362168810383328

Lee, L. (2016). Autonomous learning through task-based instruction in fully online language courses. Language Learning \& Technology, 20(2), 81-97. Retrieved from http://lt.msu.edu/issues/june2016/lee.htm

Mirzaei, A., Shakibei, L., \& Jafarpour, A. A. (2017). ZPD-Based Dynamic Assessment and Collaborative L2 Vocabulary Learning. The Journal of Asia TEFL, 14(1), 114-129. Retrieved from https://www.earticle.net/Article/A298522

Najmi, K. (2015). The effect of mobile-assisted language learning (MALL) on guided writing skill of Iranian upper-intermediate EFL learners. Journal of Applied Linguistics and Language Research, 2(4), 42-52.

Palomo-Duarte, M., Berns, A., Cejas, A., Dodero, J. M., Caballero, J. A., \& Ruiz-Rube, I. (2016). Assessing foreign language learning through mobile game-based learning 
environments. International Journal of Human Capital and Information Technology Professionals (IJHCITP), 7(2), 53-67. https://doi.org/10.4018/IJHCITP.2016040104

Parsi, P. P., \& Sanavi, R. V. (2015). The Effects of Dynamic Assessment on Improving Writing Ability of Intermediate EFL Learners. International Journal of Language Learning and Applied Linguistics World. 8(2), 73-88.

Poehner, M. E. (2007). Beyond the test: L2 dynamic assessment and the transcendence of mediated learning. The Modern Language Journal, 91(3), 323-340. https://doi.org/10.1111/j.1540-4781.2007.00583.x

Poehner, M. E. (2008). Dynamic assessment: A Vygotskian approach to understanding and promoting L2 development. Springer Science \& Business Media. Vol.9.

Poehner, M. E. (2009). Group dynamic assessment: Mediation for the L2 classroom. TESOL Quarterly, 43(3), 471-491.https://doi.org/10.1002/j.1545-7249.2009.tb00245.x

Poehner, M. E. (2011). Validity and interaction in the ZPD: Interpreting learner development through L2 dynamic assessment. International Journal of Applied Linguistics, 21(2), 244-263. https://doi.org/10.1111/j.1473-4192.2010.00277.x

Poehner, M. E., \& Infante, P. (2017). Mediated development: A Vygotskian approach to transforming second language learner abilities. TESOL Quarterly, 51(2), 332-357. https://doi.org/10.1002/tesq.308

Poehner, M. E., \& Lantolf, J. P. (2005). Dynamic assessment in the language classroom. Language Teaching Research, 9(3), 233-265. https://doi.org/10.1191/1362168805lr166oa

Ramazanpour, G., Nourdad, N., \& Nouri, N. (2016). Gender differences in the effect of dynamic assessment on grammatical accuracy of writings. Theory and Practice in Language Studies, 6(1), 90. http://dx.doi.org/10.17507/tpls.0601.12

Rashidi, N., \& Mirsalari, S. A. (2017). Investigating the Relationship Between Iranian EFL Learners' Use of Strategies in Collocating Words and Their Proficiency Level. Research in Applied Linguistics, 8(2), 93-118.

Stockwell, G. (2012). Mobile-assisted language learning. Contemporary computer-assisted language learning, 16(3), 24-31.

Tarighat, S., \& Khodabakhsh, S. (2016). Mobile-assisted language assessment: Assessing speaking. Computers in Human Behavior, 64, 409-413. https://doi.org/10.1016/j.chb.2016.07.014

Weisgerber, J. (2015). Bridging the Gap Between Instruction and Assessment: Examining the Role of Dynamic Assessment in the Oral Proficiency Skills of English-as-an-Additional-Language Learners. The Arbutus Review, 6(1), 25-40. https://doi.org/10.18357/ar.weisgerberj.612015 


\section{Macrothink}

International Journal of English Language Education

ISSN 2325-0887 2019, Vol. 7, No. 1

Xiaoxiao, L., \& Yan, L. (2010). A case study of dynamic assessment in EFL process writing. Chinese Journal of Applied Linguistics (Foreign Language Teaching \& Research Press), 33(1).

Xodabande, I. (2017). The effectiveness of social media network telegram in teaching English language pronunciation to Iranian EFL learners. Cogent Education, 4(1), 1347081. https://doi.org/10.1080/2331186X.2017.1347081

Yakışık, B. Y., \& Çakır, A. (2017). DYNAMIC ASSESSMENT OF PROSPECTIVE ENGLISH TEACHERS'SPEAKING SKILLS. European Journal of English Language Teaching, 2(1). http://dx.doi.org/10.5281/zenodo.260205

\section{Copyright Disclaimer}

Copyright for this article is retained by the author(s), with first publication rights granted to the journal.

This is an open-access article distributed under the terms and conditions of the Creative Commons Attribution license (http://creativecommons.org/licenses/by/3.0/). 